\title{
TRADE-MARK INFRINGEMENT AND UNFAIR COMPETITION
}

\author{
Rudole Callmann*
}

I

\section{METHODS OF INFRINGEMENT}

Anomalous though it may seem, no act can be labeled a trade-mark infringement without more. Whether or not the court will recognize an infringement depends upon the scope of protection to which the trade-mark is entitled under common and statutory law, and is ultimately determined by the singular approach of the immediate tribunal.

An acid test of infringement could be distilled out of a formula which recognizes that the trade-mark serves three distinct and separate purposes: (x) It identifies the product and its origin, (2) it guarantees the product's unchanged quality, and (3) it advertises the product. Injury to the trade-mark in any of its capacities as an identifying, guaranteeing, or advertising device should suffice to constitute an infringement thereof. These three functions-of different importance at different times, in different lines of business, and for different articles-are correlative. The classical function, that of identification, has molded the law of trade-marks. The importance of the guarantee function has been somewhat overestimated, while the function of advertisement still awaits full recognition and an adequate place in the law. ${ }^{1}$

A court may proceed upon any one of several acceptable grounds in granting trade-mark protection. First, a trade-mark may be protected because of the trademark statute under which it is registered. Second, a trade-mark may be protected on the theory of unfair competition if the plaintiff and the defendant are in fact competitors. Third, where the litigants are not in factual competition with each other, the court may grant protection on the theory of "unfair dealing."2 And, fourth, protection may always be predicated on the theory which treats the mark as property. Federal statutory protection is confined to the registered trade-mark; it will protect the plaintiff against a defendant's use of his mark, or an imitation thereof, in interstate commerce if such use is likely to cause confusion or mistake or to deceive purchasers. ${ }^{3}$ Under the theory of unfair competition, any trade-mark

- LL.B. r939, and Research Fellow, Harvard Law School. Member of the New York bar. Author, The Law of Unfair Compettiton and Trade Marks (1945, with cumulative supplement 1947). Contributor to legal periodicals.

${ }^{2}$ Cf. Brown, Advertising and the Public Interest: Legal Protection of Trade Symbols, 57 YALE L. T. I 66 , Ir89 $\mathrm{n.98}$ ( 1948 ).

${ }^{3}$ Cf. Vogue Co. v. Thompson-Hudson Co., 300 Fed. 509, 512 (C.C.A. 6th 1924).

'Trade-Mark Act of July 5, I946, 6o Stat. 428, 437, I5 U.S.C. \$ I052(d), I1 14(r) (I946). 
or similar device adopted by the plaintiff, registered or not, will be protected against simulation attempted by a competitor which violates the rules of fair competition and does injury to the plaintiff. The theory of unfair dealing would protect all trade-marks against injury, even if wrought by the conduct of a non-competitor, if such conduct can be characterized as a breach of the usages or ethical standards of fair dealing. ${ }^{4}$

Under the theory which recognizes the trade-mark as a property right distinct unto itself, the interest of any plaintiff in his property could be accorded protection.

Many decisions may be cited in support of each theory, but the courts have not always drawn the line precisely, and such terms as "unfair competition" and "confusion" have been loosely bandied about in opinions involving neither competition nor confusion within the meaning of those terms under the Trade-Mark Act of 1905. Dilution might have been a more appropriate operative term. Modern decisions do, however, evidence a trend that gives impetus to a certain modest optimism that our courts will, in the future, do more justice to the nature of a trademark, even though there is little reason to anticipate any greater judicial willingness to accept theoretical exactitude.

\section{A. Confusion of Origin}

The usual result of trade-mark infringement is that of passing off the goods of one as those of another. This may be effected because of two types of confusion. There may be a confusion of goods, in which event the ordinarily prudent purchaser would be induced to purchase one product in the belief that he was purchasing another. The defendant's goods are then bought as the plaintiff's, and their poorer quality reflects adversely on the plaintiff's reputation. The mark that generally identifies the source of the goods need not bear the name of, or otherwise identify, the seller; indeed, the purchasing public does not normally know the source of the article. It suffices that the public normally assumes that articles bear-

\footnotetext{
'This doctrine puts greater emphasis upon the so-called unfairness than upon competition. It tacitly assumes, of course, that certain rules of fair dealing are applicable to all, and it does not depend upon proof of a relationship between the disputants which justifies judicial action. By hypothesis, this approach has a general applicability; it is, for instance, always "unfair" to conduct one's business in violation of the ordinary law of torts. In Continental law, the entire corpus of the law of torts is founded upon a general provision against "unfair dealing" (see, for instance, Art. 1382, French Civil Code; $\$ 826$ German Civil Code). The concept of unfairness, however, is chameleon-like; its meaning varies with the many different spheres of life to which it is applicable. Standards of fairness are difficult enough to evolve where the parties are related to each other as landlord and tenant, vendor and vendee, principal and agent, trustee and beneficiary, husband and wife. For the competitive relationship, this author has soughe to devclop some maxims 'of ethics peculiarly germane to the rature of that relationship. See I Callamann, The Law of Unfair Competition and Trade-Marks 58 (1945). Absent any relationship between plaintiff and defendant, it becomes even more difficult to establish standards of fairness. It is, therefore, entirely understandable that the courts have had great difficulty in trade-mark cases involving litigants who are not in any competitive relationship. It is probable that the courts would not have resorted to the theory of unfair dealing had they been courageous enough to treat the mark as a property right entitled to protection as such; the latter concept has the advantage of analytical clarity and would eliminate the necessity of passing upon the morality of the defendant.

" 33 STat. 724 (2905), as amended, I5 U.S.C. \$81 et seq. (1946).

- See note 20 infra.
} 
ing the same mark are from the same source. From this it follows that confusion as to the origin of goods does not necessarily have reference to the actual source or to the identity of the manufacturer; the public may also conceive of the seller who advertises the goods under the mark in question as the "source."

Confusion of business is the second type of confusion. Here, though the goods of the parties are different, the defendant's product is such as might reasonably be assumed to originate with the plaintiff, and the public may then be deceived either into that belief or into the belief that there is some connection between the plaintiff and defendant which, in fact, does not exist. In either event the plaintiff's reputation is literally at the mercy of the defendant. The varying degrees and types of possible connection are, of course, myriad, and whether any connection will be assumed by the public may well depend upon the custom in the trade, as it is known to the public, whether the custom be recognized by law or not. ${ }^{7}$ In this connection, the defendant's name may create the impression that it is a corporation affiliated with the business of the plaintiff, ${ }^{8}$ or a dealer may be assumed to be in a particularly close relationship with a producer, or a service station may invoke a name that falsely identifies it as a branch of a manufacturer. ${ }^{9}$

While confusion of goods can be evident only where the litigants are actually in competition, confusion of business may arise between noncompetitive interests as well. This is true whether or not the trade-marks are registered. Section 16 of the Trade-Mark Act of 1905 , in referring to "merchandise of substantially the same descriptive properties,"10 embraces competitive and noncompetitive trade-mark infringement, but it is not so extensive as to be applicable to cases where the public would not reasonably expect the plaintiff to make or sell the same class of goods as those made or sold by the defendant. Section 32 (I) of the Lanham Act, ${ }^{11}$ which replaces Section 16 of the Act of 1905 , is even broader in its application to non-competitive trade-mark infringement; in conformity with Section $2(d),{ }^{12}$ the phrase "merchandise of substantially the same descriptive properties" has been jettisoned. This might have its most important consequence where the confusion is not one of goods or businesses but a confusion deriving out of the nature of the mark only. ${ }^{13}$

${ }^{7}$ Colorado National Co. v. Colorado Nat. Bank of Denver, 95 Colo. 386, 389, 36 P. 2d 454 (I934).

${ }^{8}$ In Colorado National Co. $\mathrm{v}$. Colorado Nat. Bank of Denver, supra note 7 , it was recognized to be a custom of banks in the United States to conduct affiliated corporations under the same name as that of the bank, except that the word "Bank" is eliminated therefrom and the word "Company" appended in its place. Hence defendant, not a bank, was denied the use of a name of such character on the ground "that it will lead customers of the plaintiff to believe that they are dealing with a corporation affiliated with the plaintiff." Id. at 456 .

${ }^{\circ}$ See Dodge Bros. v. East, 8 F. $2 d 872$ (E.D. N.Y. 1925), as to "Dodge Dealer" and "Dodge Service Station"; Ford Motor Co. v. Helms, 25 F. Supp. 698 (E.D.N.Y. I938), as to "Ford Repairs"; Yale \& Towne Mfg. Co. v. Haber, 7 F. Supp. 791 (E.D.N.Y. 1934), as to "Yale Lock Service."

${ }^{10} 33$ STAT. 728 (1905), 15 U.S.C. \$96 (I946).

1260 STAT. $437, \times 5$ U.S.C. \$III4 (I) (1946).

${ }^{22} 60$ STAT. 428 , I5 U.S.C. $\$ 1052(d)$ (1946).

${ }^{13}$ See the discussion in $\mathrm{I}(\mathrm{B})$ infra. 


\section{B. Dilution of Marks}

Although confusion of goods and businesses are the more usual results of trademark infringement, they are not the only end-products of such infringement. Therefore, it is incorrect to state that trade-mark infringement is passing off, or that the only index of such infringement is whether or not the purchaser would be induced to purchase the defendant's product instead of the plaintiff's; this has reference only to the confusion of goods, and does not cover all possible cases. Even the longcited aphorism that the law of trade-marks is "only a part of the broader field of unfair competition"14 has a rather limited validity. Though it is true that the wellspring of the law of trade-marks is the competitive relationship, it should be remembered that there may well be non-competitive violations of a trade-mark, and that in such cases logic should dictate an exception to the rule.

A trade-mark is part of the commercial equipment of a business and it is a singularly effective weapon in the competitive struggle. However, it is only that segment of the law of trade-marks which refers to the discord between competitors that is part of the law of unfair competition. If the defendant uses the trade-mark of a non-competitor, some competitive repercussions may arise. The relationship between the plaintiff and the defendant, however, would not be a competitive one if the defendant, in an unrelated business, appropriated and used the plaintiff's mark to gain an advantage over his own competitors and the plaintiff was injured thereby in his own competitive effort.

There are two kinds of non-competitive trade-mark infringement. The one discussed above involves non-competing goods which are none the less so kindred that the maker or sponsor of one might naturally be assumed to be the maker or sponsor of the other. That might mean that the ordinary industrial or commercial picture suggests the possible future expansion of the plaintiff's business so as to include the article in question. The confusion evident in such a case is confusion of businesses. The other kind of non-competitive trade-mark infringement involves non-competing goods which are entirely different from each other. There is, in all probability, no confusion in these cases at all. Here the use of the identical or very similar trade-mark by the defendant results in dilution of the distinctiveness of the plaintiff's mark.

The gravamen of a dilution complaint is that the continuous use of a mark similar to plaintiff's works an inexorably adverse effect upon the distinctiveness of the plaintiff's mark, and that, if he is powerless to prevent such use, his mark will lose its distinctiveness entirely. This injury differs materially from that arising out of the orthodox confusion; in the event that the similarity between the marks in question provokes confusion, there is an immediate or imminent loss of sales, for the confusion tends to divert potential customers from the plaintiff to the defendant. Such confusion leads to immediate injury, while dilution is an infection which, if allowed to spread, will inevitably destroy the advertising value of the mark. The

\footnotetext{
${ }^{14}$ See cases in 2 CaILManN, op. cit. supra note 4 , at $835 \mathrm{n} .47$.
} 
uniqueness or singularity of the trade-mark will sometimes be more important to the success of an advertising campaign than the quality of the product with which it is connected. The selling power of the mark is realistically dependent upon its distinctiveness. Indeed, should the trade-mark owner sanction or allow the continued use of marks similar to his own he assumes the risk that the resulting dilution will render the mark generic or available to common use. That, of course, writes finis to the distinctiveness of a mark. The fate of a trade-mark, therefore, may be dependent upon the alertness of the trade-mark owner in guarding its uniqueness and upon the alacrity with which he intervenes against imitations.

Dilution may, indeed, be the sole effect of a trade-mark infringement, but it is still problematical whether courts are willing to accept that alone as the foundation for a cause of action. While the probability of confusion is only a test of trade-mark infringement-for by means of such deceit practiced upon the public the infringer injures the business of his competitor-dilution constitutes an injury to the trade-mark by impairing its effectiveness as a selling device; it should be recognized, therefore, that dilution gives rise to a cause of action and should not be relegated to the status of a test of infringement. The wrong involved is not necessarily one affecting a competitive relationship, but is one that does injury to the property right in a trade-mark. ${ }^{15}$

The theory that dilution can be the sole basis for a cause of action has been advocated strongly by Schechter, who adopted it from the German law. But he attempted to do too much when he advanced the proposition that "the preservation of the uniqueness of a trade-mark should constitute the only rational basis for its protection."16 The American law of unfair competition and trade-marks is too deeply bedded on the concept of passing off to attempt to divorce it completely from the doctrine of confusion and public reaction to the use of the contested mark. It is indeed possible that the fact that Schechter's position was diametrically opposed to the tradition and fundamental principles of the common law was the major obstacle to its general acceptance in this country. Nevertheless, the theory is sound, and, if accepted, will offer a remedy for certain cases where presently there is none, and this without doing violence to precedent and reason.

The Dunhill ${ }^{17}$ and Tiffany ${ }^{18}$ cases are, of course, the familiar examples of "dilution." In the Dunhill case plaintiff manufactured and sold pipes, the defendant shirts. The famous jeweler Tiffany sued to enjoin the continued use of its name in connection with a motion picture house. In the former case, the court held that

\footnotetext{
${ }^{15}$ Sec Callmann, Unfair Competition without Competition? The Importance of the Property Concept in the Law of Trade-Marks, 95 U. of PA. L. Rev. 443 (r947). The author has tried to show (see his address to the Annual Convention of the American Bar Association in 1948, reprinted as One Year under the Lanham Act-A Practitioner's Viewpoint, $38 \mathrm{~T}$. M. Rep. 857 (1948)) that the concept of dilution can well be related to the concept of confusion of origin. For a recent attack on the doctrine of dilution, see note I stspra.

${ }^{10}$ Schechter, The Rational Basis of Trade-Mark Protection, 40 Harv. L. REv. 812, 83I (1927).

${ }^{17}$ Alfred Dunhill of London v. Dunhill Shirt Shop, 3 F. Supp. 487 (S.D.N.Y. I929).

${ }^{18}$ Tiffany \& Co. v. Tiffany Productions, 264 N. Y. Supp. 459 (6932), aff'd, 237 App: Div. 8or, 260 N. Y. Supp. 821 (1932), $a f f^{*} d, 262$ N. Y. 482, I 88 N. E. 30 (1933).
} 
the defendant, in adopting the plaintiff's name, was attempting to trade upon, exploit, and capitalize upon the plaintiff's well-established reputation and good will, and that the public would be induced to believe that there was a connection between the two Dunhills. In the Tiffany case, where there was some testimony to the effect that the use in defendant's motion pictures of the name Tiffany "caused confusion in [the public's] minds and led them to believe that plaintiff was connected with the production of defendant's pictures," the court decided against the defendant on the theory that "the real injury was the gradual whittling away of the identity and hold upon the public mind of plaintiff's name." In this case, however, the court, though quoting with approval from Schechter's article, ${ }^{10}$ did not accept the dilution theory unequivocally, but adverted to the issue of confusion.

Some recent decisions have displayed increasing judicial perception along these lines, ${ }^{20}$ but the optimism they generate is negated by other opinions ${ }^{21}$ which demonstrate the difficulty of familiarizing the courts with a comparatively new concept. Indeed, one is sometimes strongly inclined to join the ranks of those who clamor for legislative intervention to expedite the overly laborious common-law process of exclusion and inclusion. This author, for one, advocates a federal statute patterned upon a recent Massachusetts statute ${ }^{22}$ which provides that, in cases of trade-mark infringement and unfair competition, even in the absence of competition between the parties or confusion as to the source of goods or services, "dilution of the distinctive quality of a business name or trade-mark shall be a ground for injunctive relief."23

\section{Infringing Uses}

\section{Use of the mark in connection with defendant's goods}

The most familiar case of trade-mark infringement is that arising out of the use of the plaintiff's mark or a colorable imitation thereof in connection with the goods advertised, offered, or sold by the defendant. Usually the infringement is effected by affixing another's mark to the product or its container, or by packaging the product in a container bearing another's trade-mark. There is no distinction between the use of a trade-mark either as a merchandise mark, a service mark, or

${ }^{10}$ See note 16 supra.

${ }^{20}$ Stork Riestaurant, Inc. v. Sahati, 166 F. $2 d 348$ (C.C.A. gth 1948): Triangle Publications, Inc. v. Rohrlich, 167 F. 2d 969 (C.C.A. 2d 1948); Pro-phy-lac-tic Brush Co. v. Jordan Marsh Co., I65 F. 2d 549 (C.C.A. Ist I948); Johnston v. Twenticth Century-Fox Film Corp., 82 A.C.A. 905 (Cal. D.C. App. 1947).

${ }^{21}$ Best \& Co., Inc. v. Miller, I67 F. 2d 374 (C.C.A. 2d 1948); California Fruit Growers Exchange v. Sunkist Baking Co., I66 F. 2d 97I (C.C.A. 7th I947).

${ }^{28}$ Mass. Gen. Laws, c. I10, 87 A, approved May 2, I947.

${ }^{23}$ The salutary effect of this statute, which educates the courts with respect to the concept of dilution, is evidenced by the recent decision in The Pep Boys, Manny, Moe and Jack v. Pilavin, 77 U.S.P.Q. 265 (D. Mass. 1948). There the parties conducted similar businesses in different states; there was no actual present competition. Although the case could have been decided on the theory of potential competition under the doctrine of reasonably expectable expansion of business, through which the public might be confused, the court found in favor of plaintiff on the basis of the "likelihood of injury to business reputation or dilution of plaintiff's goodwill." See also Food Fair Stores, Inc. v. Food Fair, Inc., 79 U.S.P.Q. 114 (D. Mass. 1948); Cole of California, Inc. v. Collette of California, Inc., 79 U.S.P.Q. 267 (D. Mass. 1948). 
a business name. Thus, if the plaintiff's trade-mark is used as the defendant's business name there is a cause of action for trade-mark infringement, notwithstanding the fact that the mark may be used as a merchandise mark by the plaintiff and as a business name by the defendant. ${ }^{24}$ One who takes his trade to a business the name of which is identical with or confusingly similar to the well-established merchandise mark of another is doubtless led to believe that he is purchasing goods associated with the well-known trade-mark.

\section{Use of the mark in connection with plaintiff's goods}

Trade-mark rights differ substantially from those arising out of ownership of goods. The purchaser of goods does not acquire ownership of their trade-mark. The trade-mark owner may, if he wishes, sell his product to one buyer with his trade-mark affixed thereto, and to another without the mark. ${ }^{25}$ In the latter event, the buyer is not permitted to affix the plaintiff's trade-mark to the goods so bought. Only the trade-mark owner is entitled to identify his product by his mark and he may decide not to do so for whatever reasons he deems compelling.

In the sale of secondhand goods one may display nondeceptive signs containing the original mark. ${ }^{26}$ Unauthorized use of such a trade-mark in the secondhand dealer's business name will, however, be enjoined, because of its deceptive tendencies. ${ }^{27}$

Altered or reconditioned goods may be sold as trade-marked articles if the facts are clearly brought to the attention of prospective purchasers. In such cases the defendant may sell the article with the mark of the manufacturer on it, but the word "Repaired" or "Used" must be stamped or baked on the article in a contrasting color so as to be clearly and distinctly visible; a clarifying general statement on cartons and containers and on selling and advertising material may also be required. ${ }^{28}$ But if it is possible to obliterate the trade-mark at small cost, as, for example, in the case of burned-out electric lamps, the dealer must do so. ${ }^{29}$ If a dealer advertises as "reconditioned" articles which he has only cleaned or repaired, the trade-mark owner may sue for unfair competition. ${ }^{30}$

\footnotetext{
"Certified copies of a corporation's articles of incorporation are, therefore, recorded in the Patent Office for search purposes. The business name of an individual is not entitled to such recordation. Ex parte Magi Co., 36 T. M. Rep. 248 (Commissioner of Patents 1946).

${ }^{25}$ Of course, this would not be allowed if such a practice would amount to deceptive advertisement.

${ }^{93}$ Singer Mfg. Co. v. Seinfeld, 89 F. 2d 35 (C.C.A. 2d I937); Bureau of National Literature v. Sells, 21I Fed. 379 (W.D.Wash. I9I4).

${ }^{27}$ Dodge Bros. v. East, 8 F. 2d 872 (E.D.N.Y. 1925).

${ }^{28}$ Champion Spark Plug Co. v. Sanders, 329 U. S. 709 (I947), affirming 156 F. $2 d{ }_{488}$ (C.C.A. 2d 1946$)$.

${ }^{20}$ General Electric Co. v. Re-New Lamp Co., I21 Fed. 164, I65 (C.C.D. Mass. 1903); I28 Fed. 154 (C.C.D. Mass. 1904); Green v. Electric Vacuum Cleaner Co., I32 F. 2d 3I2 (C.C.A. 6th I942); RESTATEMENT, TORTS \$737 (1934).

${ }^{30}$ Champion Spark Plug Co. v. Reich, 24 F. Supp. 945 (W.D.Mo. I938); Champion Spark Plug Co. v. Emener, 16 F. Supp. 816 (E.D.Mich. 1936); noted by Derenberg in Sale of Reconditioned Article as Trade-Mark Infringement, 32 Bull. U. S. Trade-Mark Ass's 15 (1937). In the last-cited case, the court gave advice relative to distinguishing the defendant's spark plugs, e.g., painting red the metal parts of the defendant's plugs (referring to Champion Spark Plug Co. v. A. R. Mosler \& Co., 233 Fed. II2 (S.D.N.Y. rgr6)), removing the trade-mark by sandblasting or acid and painting the word "Used" with
} 


\section{Replacement parts}

It is beyond dispute that any manufacturer is entitled to make repair parts for an article not manufactured by him if those parts are not patented by the manufacturer of the entire unit, and being so entitled he is also permitted to announce the fact that his wares are intended as spares or replacements for the main article. In other words, "it is lawful for one manufacturer to call attention to the fact that the repair or renewal parts as made by him will fit into the commodity which is manufactured by another." 31 He is therefore entitled to protection against the prime manufacturer's "quite natural desire to draw unto itself, if possible, the exclusive right of furnishing repair parts to its patented machines. The consummation of this purpose, however, no matter how natural on the part of complainant, or how devoutly wished, would, in the end, result in the upbuilding of such monopolies in trade and business as would not be welcomed by the purchasing public." ${ }^{2}$ Conversely, it should also be recognized that the manufacturer of the main product may be desirous of protection against the inferior quality of such spare parts made by another and intended for his article. The superior workmanship or quality of materials put out by the main manufacturer may sometimes be compensated by the higher price paid to him, but, in most instances, standardization of goods has led to a levelling of price. Therefore, subject to the limitation that he must not unjustifiably disparage his competitor's product, the original manufacturer can resort only to publicizing a caveat against any substitutes offered by others not under his supervision or control. ${ }^{33}$

To what extent the manufacturer of spare parts is entitled to use the trade-mark of the prime manufacturer of the entire unit, without infringing upon the latter's rights as the trade-mark owner, is the basic issue. Such a trade-mark use can have a twofold effect: the public may be led into the belief that the repair parts offered by the second manufacturer originate with the prime manufacturer of the unit, and the trade-mark of the latter may, by its descriptive use in the advertisements of the former, be either diluted or converted into a generic designation of a merchandise type. Courts are, therefore, alert to impose upon the maker of the parts the duty of avoiding any representation that could lead to confusion or dilution and also the duty of advising the public unequivocally that the parts offered by him are not made by the trade-mark owner.

\footnotetext{
"heavy white paint" (p. 825). Cf. Bureau of National Literature v. Sells, 2 II Fed. 379 (W.D.Wash. I914).

31 American Safety Razor Corp. v. International Safety Razor Corp., 26 F. 2d Io8, 110 (D.N.J. 1928), rev'd on other grounds, 34 F. 2d 445 (C.C.A. 3d 1929).

${ }^{82}$ Pyle National Co. v. Oliver Electric Mfg. Co., $28 \mathrm{I}$ Fed. 632, 635 (C.C.A. 8th 1922), cert. denied, 260 U. S. 736 (I922).

${ }^{83}$ Cf. Judson L. Thomson Mfg. Co. v. Federal Trade Commission, 150 F. 2d 952, 958 (C.C.A. 1st r945), discussing an exclusive-dealing arrangement and a tying contract: "The open market not the court should be the forum for the presentation of claims as to the merits of tied articles. The lessees are quite capable of judging for themselves in an atmosphere of competition whether or not rivets of one manufacturer will work in the machines of another."
} 
Therefore, an injunction will not issue against the defendant if he merely states that the articles he offers are patterned upon the type of the article also manufactured by the trade-mark owner and are designed to fit into the main article; he may adopt a "collateral" use of the trade-mark, but he may not use it conspicuously as a catchword..$^{31} \mathrm{He}$ is by no means allowed to place the trade-mark of the original manufacturer on the parts, since this is a representation to the ultimate purchaser of their origin with the plaintiff. ${ }^{35}$

\section{Advertising substitutes}

Such terms as "substitute for," "made like," "similar to," or "as good as" the plaintiff's trade-marked article, though they would appear to be innocuously descriptive, are sometimes expressly designed to capitalize upon the selling power of plaintiff's mark. If the plaintiff's competitors are permitted to refer thus to his mark, he will be powerless to prevent it from becoming generic. Any such trademark use by competitors necessarily involves dilution. Only those words in common use that are genuinely descriptive, irrespective of whether they have always been so regarded or whether they have so developed, can be adopted with impunity. The use of such phrases as those mentioned above in effect hitches the plaintiff's horses to the defendant's carriage. Thus, for example, a defendant was properly enjoined from using such phrases as "Introduced as Protargol," "Introduced as Veronal," and even "Veronal Equivalent."36 It does not require a very penetrating analysis to perceive that there are at least two cogent reasons for outlawing such a representation. It is patently incongruous to allow a defendant, in competition with the plaintiff, to capitalize upon the plaintiff's own advertising device. It seems only fair that the defendant should be required to bring his product to the attention of the public by means of his own effort and ingenuity. Secondly, by such representations the defendant is impliedly comparing his article with the plaintiff's, and he is moreover acting as a judge in his own cause.

With respect to the rule of necessity, it is conceded that if the word adopted by the defendant is legitimately descriptive, or if the trade-mark of the plaintiff has a

\footnotetext{
"An advertisement for razor blades, declaring that they "Will Fit Sha-ve-zee, Gem, Liberty, EverReady, and other razors," with those names in large type and the phrase, "and other razors," in small print, has been enjoined. American Safety Razor Corp. v. International Safety Razor Corp., 34 F. 2d 445 (C.C.A. 3d I929). However, such slogans as "to fit Auto-Lite" (Electric Auto-Lite Co. v. P. \& D. Mfg. Co., 78 F. 2d 700 (C.C.A. 2d 1935)) or "Chelsea Cook grates, Nos. 7 and 8" (Magee Furnace Co. v. Le Barron, I27 Mass. I15 (1879)) or “calendar pads fit (plaintiff's) 'Perfection' or 'Gem' or 'Jumbo Gem' bases" (Columbian Art Works v. Defiance Sales Corp., 45 F. 2 d 342 (C.C.A. 7th r930)) were allowed.

${ }^{38}$ Metal Stamping Corp. v. General Motors Corp., 33 F. 2d 4 II (C.C.A. 7th 1929) (hub caps for 2utomobiles); Ford Motor Co. v. Wilson, 223 Fed. 808 (D.R.I. I915), Ford Motor Co. v. Helms, 25 F. Supp. 698 (E.D.N.Y. I938) (parts for Ford autos advertised as "Ford Articles"); Moline Plow Co. v. Omaha Iron Store Co., 235 Fed. 519 (C.C.A. 8th rgr6), cert. derzied, 242 U. S. 649 (19I7) (plowshares); Duro Co. (of Ohio) v. Duro Co. (of New Jersey), 27 F. 2d 339 (C.C.A. 3d r928) (spark plugs for internal combustion engines); Yale \& Towne Mfg. Co. v. Haber, 7 F. Supp. 791 (E.D.N.Y. 1934) ("Yale Lock Service"); Scranton Stove Works v. Clark, 255 Pa. 23, 99 Atl. I7o (Igr6) (repair parts for stoves).

${ }^{20}$ Winthrop Chemical Co. v. Blackman, 246 App. Div. 234, 285 N. Y. Supp. 443 (1936). See also Hohner v. Gratz, 52 Fed. 87 I (C.C.S.D.N.Y. I892).
} 
"primary meaning" of descriptive significance, or has become the accepted name for a method or system, the defendant will be allowed to include it inconspicuously in a sentence; trade-mark use, however, is not permissible in any case. A defendant is confronted with the same problems that confronted the plaintiff when he first entered the market, and he is to be put to the test of advertising his craftmanship as successfully as did the plaintiff and by his own devices.

\section{Repacking, rebottling, and resale of bulk goods}

The defendant infringes upon the plaintiff's trade-mark not only when he attaches to his product the same or a confusingly similar mark, but also when he sells, without authorization, the plaintiff's product with its trade-mark, after repacking, refilling, or rebottling. In the leading case of Prestonettes $v$. Coty," ${ }^{37} \mathrm{Mr}$. Justice Holmes lent the prestige of his great name to a doctrine that does not appeal very greatly to the sense of fairness of the ordinary man and that has been critically analyzed by experts in the field."38 The facts of this case are as follows: The defendant bought the plaintiff's "Coty" face powder and "L'Origan" perfume, subjected the powder to pressure, added a binder, and then sold the compact in a metal case to which the plaintiff's mark was affixed. He also rebottled the perfume, and sold it in smaller containers bearing the plaintiff's mark. The Court of Appeals granted an absolute preliminary injunction against any use of the plaintiff's marks except in connection with the original packages. The Supreme Court, however, reversed, grounding its decision upon the defendant's rights of ownership and his privilege to tell the truth. Accordingly the defendant was permitted the use of the following legend on the labels of the rebottled perfume: "Prestonettes Inc., not connected with Coty, states that the contents are Coty's (giving the name of the article) independently rebottled in New York." Similar explanatory provisions were ordered in other cases. ${ }^{39}$

With respect to registered trade-marks, the Lanham Bill suggested protection of the trade-mark owner against repacking and refilling only if the product, its package, or its container bears "notice that the goods may be resold only unaltered or in the original package or container." This provision was finally eliminated on

${ }^{37}{ }_{26}$ U. S. 359 . (x924).

${ }^{s 8}$ Clark, J., in Bourjois, Inc. v. Hermida Laboratories, ro6 F. 2d r74 (C.C.A. 3d 1939).

${ }^{39}$ Coty v. Ivory Novelties Trading Co., I2 T. M. Rep. 284 (S.D.N.Y. I922); Caron Corp. v. Importers Exchange, 13 T. M. Rep. 355 (S.D.N.Y. 1923); Guerlain Perfumery Corp., of Delaware v. Klcin, 57 F. 2d 724 (E.D.N.Y. 1932); R. B. Semler V. Kirk, 27 F. Supp. 630 (E.D.Pa, 1938); Bayer Co. v. Shoyer, 27 F. Supp. 633 (E.D.Pa. 1939). In Coty v. Leo Blume, 24 F. 2 d 924, 925 (C.C.A. $2 d$ 1928) the Second Circuit Court of Appeals interpreted its decree in Coty, Inc. v. Prestonettcs, Inc., 3 F. $2 d$ 984 (C.C.A. $2 \mathrm{~d}$ 1924): "It is true that the appeal was brought by the plaintiff, who sought even broader protection, and that the defendant in that litigation raised no objection to the form of the decree; consequently our decision was not an actual holding that a repacker or rebottler, whose label refers to competitors' produets, must state the pereentages of those products which have gone into his compound. But we think such a requirement entirely reasonable. Buyers ought to know how much of the Coty perfume they are getting; that is a reasonable protection to plaintiff, as they may buy on the Coty name, and it is no burden on the seller, if he is honestly trying to sell the compound on its own merits." The Third Circuit Court of Appeals followed the Supreme Court in Bourjois, Inc. v. Hermida Laboratories, ro6 F. 2d 174 (C.C.A. 3d r939). 
the ground that the courts alone should decide whether and under what circumstances such practices constitute infringement or unfair competition.

II

\section{Protection Against the Trade-Mark Owner}

\section{A. Free Use of Descriptive Designations}

Unless the mark is a meaningless, arbitrary, or fanciful word, a mark evolves out of the transformation of common words or pictures from their general or primary meaning into a trade-mark of secondary meaning or out of the adaptation of primary meaning to a trade-mark use. ${ }^{40}$ In many instances the secondary meaning of a word may be more cogent than its primary meaning; indeed, a secondary meaning may be sufficiently strong to dissipate any primary meaning the word may once have had. Therefore, competitors of the trade-mark owner will be tempted to adopt. the secondary meaning, and it may sometimes be quite difficult to avoid the prominence of the secondary meaning without extraordinary effort. Courts have, therefore, established three basic indices of fair competition. First, no competitor is allowed to claim the right to use the word in its primary meaning if it is clear that he does so in furtherance of unfair competition. Second, a competitor's use of a word in its primary meaning constitutes unfair competition if it is likely to provoke confusion, unless, of course, such a use is dictated by patent commercial necessity. Third, there is imposed upon all competitors of the trade-mark owner the affirmative duty of taking all precautions reasonably necessary to avoid confusion.

It is within the court's province to determine whether the particular usage is referable to its primary or secondary sense.11 The former is non-trade-mark use, i.e., a use designed to inform the public that the article is of a particular quality or origin. The other is trade-mark use, i.e., a use which is patently calculated to call the public's attention to the symbol of the advertised article. Trade-mark use is, analytically, a catchword use. Only a conspicuous position invites public attention. Thus, even a single word prominently placed and flanked by the dress of an article, as distinguished from the use of the same word in a sentence, amounts to a trade-mark use. "Bestyette," for example, is sufficiently distinctive as a trademark when contrasted with such a sentence as: "These rain capes are the best yet made," or "Best Rain Capes Yet Made," or "Best Yet Made."42

The law has been summarized thus:

When the word is incapable of becoming a valid trade-mark, because descriptive or geographical, yet has by use come to stand for a particular maker or vendor, its use by another in this secondary sense will be restrained as unfair and fraudulent competition,

${ }^{10}$ In Wotherspoon v. Currie, L. R. 5 H. L. 508 ( 1872 ), the Glenfield Starch case, Lord Westbury said that the name of the place "Glenfield" had become a trade denomination for the plaintiff's starch; it no longer had its ordinary meaning, and, in connection with starch, had acquired a peculiar secondary significance.

${ }^{11}$ Cohen v. Nagle, Igo Mass. 4, 76 N. E. 276 (I906).

${ }^{12}$ New York Mackintosh Co. v. Flam, 198 Fed. 57 I (S.D.N.Y. I912). 
and its use in its primary or common sense confined in such a way as will prevent a probable deceit by enabling one maker or vendor to sell his article as the product of another. ${ }^{43}$

In language broad enough to provide against all loopholes, Section 33(b) (4) of the Lanham Act declares that a use is free only if it is "otherwise than as a tradeor service-mark" and also if it is made "fairly and in good faith."44

Where the defendant seeks to justify the use of a common word by the argument that he needs it to tell the truth simply, ${ }^{45}$ courts have evolved a measuring rod to test whether there is an "unnecessary use" by the defendant. ${ }^{40}$ In judicial opinion, the concept of necessity is evoked not as a standard of legality, but rather as a test for an illegal intent. It is the reverse application of the competitor's affirmative duty to take such reasonable precautions as will avoid confusion. If it is evident that there is no real necessity for the use of a particular term, because there are others of equal effect and in common use, ${ }^{47}$ or if the defendant cannot offer a reasonable explanation for his particular usage, there then arises a strong presumption that it was born out of the intention to further unfair competition. ${ }^{48}$

The burden rests with the defendant to justify his use. It is his task to convince the court that he has a right to that term and that his right has been exercised with reasonable regard and respect for the rights of the trade-mark owner. ${ }^{10}$

\section{B. Defendant's Use of His Own Name}

"The right of a man to use his own name in his own business is part of the natural and inalienable rights guaranteed by the very first clause of our Constitution, without which the right to acquire, possess and protect property would be of

${ }^{43}$ Computing Scale Co. v. Standard Computing Scale Co., Ir8 Fed. 965, 967 (C.C.A. 6th 1902).

4 6o STAT. 438 , 15 U.S.C. \$1 II5 (b) (4) (1946).

${ }^{45}$ The statement in Delaware \& H. Canal Co. v. Clark, I3 Wall. 311,327 (U. S. I87I), that "Equity will not enjoin against telling the truth" does not hold true in cases of unfair competition where perfectly legal means may be used to reach unfair results and where a truthful disparagement may be as unfair as a lie. This "remark must be limited to cases where the truth is honestly told, and can have no application to a case where it is told with intent to deceive and does deceive." See American Brewing Co. v. St. Louis Brewing Co., 47 Mo. App. 14 (189I).

${ }^{40}$ Fuller v. Huff, 104 Fed. I4I (C.C.A. 2d 1900), reversing 99 Fed. 439 (C.C.S.D.N.Y. I899); Hartzler v. Goshen Churn and Ladder Co., 55 Ind. App. 455, 467, 104 N. E. 34, 38 (1914): "It is unnecessary for the subsequent trader to use such terms in such a manner as to give his goods the same short name in the market as that of the prior trader's goods, for it is easy to use such terms in some other honestly descriptive way without injury to any right of either party."

${ }^{47}$ Scriven v. North, 134 Fed. 366, 375 (C.C.A. $4^{\text {th }}$ r904) modifying I24 Fed. 894 (C.C.D.Md. 1903): "A stamp with the words printed in straight lines would identify the defendants' goods as easily as the oval stamp. Granted that the oval form is in common use, the straight is equally common, and was, in fact, used formerly by defendants and complainants alike; and when the proof shows, as it does, that after the complainants adopted the oval form the defendants adopted a stamp resembling it, when they show no good reason for such change, or any reason at all, exccpt that, being a common form, they had the right to use it as well as complainants, and when we find, as we do, that there is a resemblance between the two, and no reason appears for such resemblance, except that it was calculated to deceive, we must conclude that it wás adopted for that purpose."

${ }^{18}$ Lever Bros. Co. v. Sitroux Co., Iog F. $2 d 445,448$ (C.C.P.A. I940); Paris Medicine Co. v. W. H. Hill Co., I02 Fed. 148, 15I (C.C.A. 6th 1900); Grocers Baking Co. v. Sigler, 132 F. 2d 498 (C.C.A: 6th I942).

10 Jacobs v. Beecham, 22I U. S. 263, 27 I (19rI), affrrming 159 Fed. 12g (C.C.A." 2d 1908); Standard Oil Co. v. California Peach and Fig Growers, 28 F. 2d"283 (D.Del. r928). 
little worth." business has not been denied merely because another, similarly named, is already so engaged under his name. ${ }^{51}$ If deception is nevertheless likely and confusion as to the origin of the goods probable, the courts have held that these circumstances arise from the exercise of legal rights unprovoked by any wrongful act, ${ }^{52}$ and therefore that they are to the plaintiff damnum absque injuria. ${ }^{53}$ Only when a palpable fraud characterizes the defendant's use of his own name in business will an absolute injunction issue against the continued use. Stated otherwise, it must be established that the defendant's use of his own name is accompanied by an affirmative act or "artifice" "calculated to deceive."54 Courts have not yet recognized any distinction between those cases in which the defendant ventures into the plaintiff's business because he actually wants to engage in that particular field and those in which he does so merely to capitalize upon his fortunate name. ${ }^{55}$

In the Waterman Pen case, Mr. Justice Holmes declared:

It now is established that when the use of his own name upon his goods by a later competitor will and does lead the public to understand that those goods are the product of a concern already established and well known under that name, and when the profit of the confusion is known to and, if that be material, is intended by the later man, the law will require him to take reasonable precautions to prevent the mistake.56

The extent of that duty to take such precautions is limited by the defendant's allegedly "sacred and inalienable right" to the use of his own name in business. Courts

${ }^{\text {to }}$ Hilton v. Hilton, 89 N. J. Eq. I82, I83, 104 Atl. 375 (Igr8), modifying 89 N. J. Eq. I49, 102 Atl. 16 (1917).

${ }^{11}$ Brown Chemical Co. v. Meyer, 139 U. S. 540 (I891), affirming 31 Fed. 453 (C.C.E.D.Mo. I887); Fidelity Bond \& Mortgage Co. v. Fidelity Mortgage Co., 12 F. 2d 582 (C.C.A. 6th I926); Moon Brothers v. Moon, 300 Mich. 150, I N. W. 2 d 488 (I942); Edelstein v. Edelstein, 6 S. W. 2d 400 ('Tex. Civ. App. 1928); Goidl v. Advance Neckwear Co., r23 S. W. 2d 865 (Tex. 1939), affirming 98 S. W. 2d 364 (Tex. Civ. App. 1936), following Howe Scale Co. v. Wyckoff, Seamans \& Benedict, I98 U. S. 118 (1905), reversing Wyckoff, Seamans \& Benedict v. Howe Scale Co., I22 Fed. 348 (C.C.A. 2d 1903), reversing r mo Fed. 520 (C.C.D.Vt. rgor), and Herring-Hall-Marvin Safe Co. v. Hall's Safe Co., 208 U. S. 554 (1908), affirming I46 Fed. 37 (C.C.A. 6th 1906).

tas Andrew Jergens Co. v. Woodbury, 273 Fed. 952, 966 (D.Del. I921), affd, 279 Fed. ror6 (r922), cert. denied, 260 U. S. 728 (Ig22); Brown Sheet Iron \& Steel Co. v. Brown Steel Tank Co., I98 Minn. 276,269 N. W. 633 (1936).

${ }^{83}$ Guth Chocolate Co. v. Guth, 215 Fed. 750 (D.Md. I914), $a f \prime d, 224$ Fed. 932 (C.C.A. 4th I915), cert. denied, 239 U. S. 640 (I915); Goldwyn Pictures Corp. v. Goldwyn, 296 Fed. 391 (C.C.A. 2d 1924); Da Pron v. Russell, 87 Colo. 394, 288 Pac. I78 (1930); Russia Cement Co. v. Le Page, I47 Mass. 206, 209, I7 N. E. 304 (I888); Burns v. William J. Burns International Detective Agency, 235 Mass. 553, 556, 127 N. E. 334 (1920); Seligman v. Fenton, 286 Pa. 372, 375, 133 Atl. 561 (I926).

"6 Howe Scale Co. v. Wyckoff, Seamans \& Benedict, I98 U. S. 118, r37 (1905), reversing r22 Fed. 348 (I903); Ralph Bros. Furniture Co. v. Ralph, 26 Northampton 29I (Pa. r938). Such an artifice was evident in De Youngs v. Jung, 27 N. Y. Supp. 370 (1894), where the plaintiff's name was "De Youngs" and the defendant "Jung" changed his name to "The Youngs." The case of Holland Furnace Co. v. New Holland Mach. Co., 24 F. 2d 75I (E.D.Pa. 1927), is not in line with the authorities.

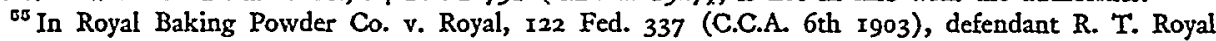
was a manufacturer of bicycles and bicycle sundries, who, only because of his name, went into the baking powder business. He was ordered to "present his own name in the least conspicuous manner possible consistent with the right to place his name and address upon the goods made by him" (p. 348).

${ }^{86}$ L. E. Waterman Co. v. Modern Pen Co., 235 U. S. 88, 94 (1914), affirming x97 Fed. 534 (1912). In J. \& J. Cash v. Cash, I8 Rep. Pat. Cas. 213 (I901), I9 Rep. Pat. Cas. I8I (I902), Kekcwich, J., granted an absolute injunction restraining the use of the name Cash. The Court of Appeals altered this by adding "without taking reasonable precautions to distinguish, etc." 
have leaned heavily upon the type of explanatory phrase which presumably distinguishes the defendant by" the declaration that he is not connected with the "original" or "genuine" bearer of the name, ${ }^{57}$ and that which distinguishes the plaintiff by the announcement that the defendant is distinct from, and has no affiliation whatever with, him.

The books are, however, replete with other cases, in which the results were even less satisfactory than those in which the inclusion of an explanatory phrase was directed. It has, for example, been held sufficiently distinguishing if a word describing a line of business, the first name, a second family name, initials, or even a suffix, is added to the famous name, or even if the defendant merely avoids a plural or possessive form of the name.

The Chickering and Perkins cases point the way to a more realistic resolution of the thorny problem presented by the family name. In the Chickering case ${ }^{58}$ the court ordered the defendanit to adopt a uniform and fanciful name, such as "Acoustigrande," for all its pianos, while permitting the use of its own name, in smaller type, merely for the purpose of indicating by whom the pianos were made. Thus the court recognized and protected the exclusive right of the plaintiff to the secondary meaning of the name and still allowed the defendants to "use the common word in its common meaning." fendant from every trade-mark use of the name Perkins, but allowed the defendant to use the firm name H. K. Perkins \& Co.

The law differs with respect to corporate names. The choice of such a name is the result of a deliberate act of the incorporators, and there is patently no commercial necessity to justify the adoption of the name of an individual."1 "The name given to a corporation is an artificial and impersonal thing which can be selected from an entire vocabulary of names." 22 Therefore, the rule that one may use his own name in business even though such a use would prove detrimental to a previously established business cannot be invoked to justify the use of a corporate name of which an individual's name is a part.

The same line of reasoning should be equally applicable to partnerships. ${ }^{03}$

${ }^{57}$ In Nestor Johnson Mfg. Co. v. Alfred Johnson Skate Co., 313 Ill. 106, 144 N. E. 787 (1924), reversing 229 Ill. App. 549 (1923), the court modified such an injunction by deleting the word "original," the effect of which had compelled the defendant to slander his own goods. See Note, $3^{8}$ HARv. L. REv. 405 (1925).

${ }^{58}$ Chickering v. Chickering \& Sons, 215 Fed. 490 (C.C.A. 7th 1914).

${ }^{60} \mathrm{Id}$. at 495 .

${ }^{10}$ Henry Perkins Co. v. Perkins, 246 Mass. 96, 140 N. E. 461 (1923).

${ }^{61}$ Chas. S. Higgins Co. v. Higgins Soap Co., r 44 N. Y. 462,39 N. E. 490 (r895), reversing 7I Hun IOI, 24 N. X. Supp. 80I (1893).

${ }^{62}$ De Long v. De Long Hook \& Eye Co., 32 N. Y. Supp. 203, 206 (I894), modified, 89 Hun 399, 35 N. Y. Supp. 509 ( 1894$)$.

${ }_{63}$ Tomsky v. Clark, 73 Cal. App. 4x2, 238 Pac. 950 (1925); Rubel v. Allegretti Chocolate Cream Co., I77 Ill. 129, 52 N. E. 487 (1898). In Frazier v. Dowling, 198 Ky. L. Rep. 1109, 39 S. W. 45, 46 (1897), the plaintiff, famous in connection with the name "Waterfill \& Frazier Whiskey," brought action against two partners, Waterfill and Frazier, who had discarded their originally unobjectionable business name and changed to "Waterfill \& Frazier, Distillers." The court found "that this combination [did not represent] the name of cither of the partners in the new concern. . . If the sole object in using this combination was to tell the truth ... it does not do so any more than did the discarded 


\section{III}

\section{Conclusion}

Despite the fact that the concept of infringement is as old as trade-mark law, and that it figures in almost every trade-mark opinion-and there have been many-it is apparent that it did not spring forth full-born. It is indeed still an extremely volatile concept, which varies with human ingenuity. Precedent in the law can be stultifying if applied blindly, and thus the virtue turned to vice. It is to be hoped that our courts can avoid the temptation to compress that concept into welldefined molds and can shape it as the potter shapes his clay to the job before him.

brand 'G. G. Frazier \& Company,' or 'J. M. Waterfill \& Company.'" See also Dr. A. Posner Shoes, Inc. v. Posner, io T. M. Rep. II8, Ix9 (N.Y. Sup. Ct. I920), where two former employees, Posner and Schwartz, formed a partnership; the defendants were enjoined "from placing that mark in any shield, or with a lattice design, or in which the word 'Posner' shall appear separate from the word 'Schwartz' or in larger or more conspicuous lettering than the word 'Schwartz' or in a different line from that word, or continuing any method of business calculated to deceive." International Silver Co. v. William H. Rogers Corp., 67 N. T. Eq. 646, 60 Atl. I87 (Ig05), reversing 66 N. J. Eq. II9, 57 Atl. I037 (1904). See also Goldberg v. Goldberg, I59 Ga. 761, x26 S. E. 823 (x925), where, though two of the three defendant partners bore the name "Goldberg," its use was enjoined entirely. But compare Lucile, Ltd., New York and Paris v. Schrier, rgr App. Div. 567, r8x N. Y. Supp. 694 (1920). The plaintiff was well known to the public as "Lucile," and the defendant partnership of Lucille Schrier and Byrdie Levy used as its trade name "Lucille-Byrd." Defendants were permitted to use the name of Lucille Schrier alone or in conjunction with the other partner's name in letters of the same style, type, and conspicuousness, the court citing Bernhard v. Bernhard, 156 App. Div. 739, 142 N. Y. Supp. 94 (I913); World's Dispensary Medical Ass'n v. Pierce, 203 N. Y. 4I9, 96 N. E. 738 (IgII), modifying 138 App. Div. 40r, x22 N. Y. Supp. 818 (rgro). See also Ralph Bros. Furniture Co. v. Ralph, 338 Pa. 360 , r2 A. 2d 573 (1940). Cf. also L. E. Waterman Co. v. Modern Pen Co., supra note 56. 